\title{
Decentralization in Educational Disparity of the Southeast Sulawesi Province
}

\author{
Obed Bida ${ }^{1}$
}

\begin{abstract}
Educational disparity is a public issue that continues to be an endless subject matter of discourse due to the highly centralistic process of education policy in the government bureaucracy. This research aims to understand the pattern of educational disparity occurring in the islands of Southeast Sulawesi Province, Indonesia. The role of political actors in the success of education policy is a vital element in the policy process, and this is apparent in the significance of the political aspect in the education policy process, which emphasizes more on political approaches rather than actual social, economic, and geographical conditions. This study was conducted using the descriptive qualitative approach with data collection techniques that included observations, in-depth interviews, and document analysis in Buton and South Buton Regencies. Study results indicate that the education policy pattern developing in island regions is inclined to using the spatial approach with a central area priority scale, and the structural elite approach, which is political lobbying employed by structural elites (school principals) targeting education bureaucracy in the region. The education policy pattern developing in the region actually has an impact on educational disparity in the public, both at the district and regency levels. In general, the education decentralization policy has yet to run optimally on account of educational resources in the region being distributed by using the spatial and structural elite approaches which have, consequently, created a pathological behavior in the education bureaucracy that is chockfull of vested interests.
\end{abstract}

\section{Keywords:}

public policy; decentralization; educational disparity

\section{Introduction}

Study on educational disparity within the discourse of public administration studies has yet to develop adequately. The interest of conducting studies on educational disparity is much more nascent in social sciences such as sociology, cultural studies, economics, and education sciences. The source of the education problem confronted by Indonesia today is the low access and quality of education along with the ever widening gap in educational disparity among the public brought about by socio-cultural, economic, and geographical conditions (Walter, 2001; Montt, 2011; Dorius, 2013; Lewis, 2007). Thus, a discourse on educational disparity within the perspective of policy as a part of public issues serves as a significant and appealing matter in order to understand government (state) policies in managing education. Through education, the society is expected to improve both their economic and cultural lives, as well as their position within the social structure. Although the hope of equal chance and opportunity still remains a myth in the society (Drost, 1998).

\footnotetext{
${ }^{1}$ Department of Public Administration, Faculty of Law, Social and Political Sciences, Open University. Email: obida@ecampus ut.ac.id
} 
The education system, which has been managed within a centralistic bureaucratic climate, is considered as one of the causes of disparity and deteriorating quality of education in the society. This is due to the fact that the bureaucratic system continues to place "power" as the most determining factor in the decision-making process (Budge \& Keman, 1990). The shift of the political system from centralization to decentralization has brought new expectations for the regional governments to take greater responsibility in the implementation of education. In its development, the decentralization policy has undergone numerous obstacles and has not been running effectively on account of the political elites' dominance in the regions and the inclination to emphasize political approaches, which are full of interests and undemocratic, leaving regional governments susceptible to the elite capture phenomenon (Bardhan \& Mookherjee, 2005; Malley, 2003).

Diverse experiences from developing countries implementing the regional autonomy policy indicate that the policy actually has the potential of inducing problems relating to clashes of interests between the central and regional governments (Fiske, 1998). The development of central-regional government relations often wax and wane, wherein there are generally two tendencies, which are a centralistic relationship based on the idea that the progress of national education can only be accomplished with the central government having full control of education in a centralized manner for the sake of efficiency and efficacy. Meanwhile, based on reality, the centralization of authority/power, would, automatically, only provide advantage to the central government and increasingly marginalize the regional governments instead. The degradation of education quality, inefficiencies in education management, education gap, limited mobility and space for public participation in education, and diminishing demands for government accountability pertaining to education. These issues have led to the suboptimal functioning of education policy as an effective tool to achieve the goals of national education, which is caused by numerous stipulated education policies often containing inconsistent and vague orientations (Wibowo, 2015).

A similar argument is presented by Nelson (1996), the problems arising in education concern the declining quality of students, the low level of teacher and community welfare, the steep cost of education, and the lack of education facilities and infrastructure managed by the government, consequently causing disparity and unequal public access to education. This has subsequently become a seemingly incessant debate topic and a hot issue in the world of education. Numerous education policies and programs have been established by the central and regional governments to improve access to and quality of education, yet it seems that these education policies are not sensitive to the need of communities with poor social, cultural, and economic conditions, particularly those living in remote areas and islands making it even more difficult for students to remain in school (Nguyen, 2011).

Education policies concerning access to and quality of education continue to confront a winding and arduous road because the education gap among schools and regions in Indonesia remains present in the world of education and has always been a never-ending debate among scholars and practitioners alike. This is in line with the statement of the Indonesian Ministry of Education and Culture (Kementerian Pendidikan dan Budaya - Kemendikbud) (2016) that the quality of education is still considered low because it is unable to fully provide the appropriate competencies in accordance with the education level undertaken by the learners, among the issues are (1) insufficient availability of educators, in terms of both quantity and quality, (2) low level of welfare for educators, 
Table 1.

Assessment of Education Conditions in Indonesia

\begin{tabular}{|c|l|}
\hline Year & \multicolumn{1}{|c|}{ Education Conditions in Indonesia } \\
\hline 2012 & $\begin{array}{l}75 \% \text { of schools did not meet minimum service standards (40,000 schools), and 44.5 was the average score } \\
\text { in the teacher competence examination in which the expected standard was a score of 70 or approximately } \\
460,000 \text { teachers. }\end{array}$ \\
\hline 2013 & Ranked 49 out of 50 countries in terms of higher education quality. \\
\hline 2014 & $\begin{array}{l}\text { Ranked } 40 \text { out of } 40 \text { countries according to The Learning Curve Pearson 2014 report (mapping of education } \\
\text { quality and access). }\end{array}$ \\
\hline 2015 & $\begin{array}{l}\text { Ranked } 69 \text { out of } 76 \text { countries according to PISA (Program for International Student Assessment) relating } \\
\text { to achievements in educational performance. }\end{array}$ \\
\hline 2016 & Ranked 36 out of 49 countries according to the TIMSS assessment in the field of science literacy. \\
\hline
\end{tabular}

Source: Indonesian Ministry of Education and Culture (2016)

(3) unequal provision of education facilities, and (4) insufficient provision of operational cost for education.

However, the allocation of education budget in the State Budget (Anggaran Pendapatan dan Belanja Negara - APBN) shows an annual increase from as many as 408.5 trillion rupiahs in 2015 to 416.6 trillion in 2016 (Indonesian Ministry of Finance, 2016). Even so, the amount of education budget spent by the central government in the last five years has not resulted in better access to and quality of education amongst the public. The current condition of education in Indonesia is, in fact, still experiencing exceedingly complex issues and is heading toward a state of emergency. ${ }^{2}$ Conceptual wise, policies related to improving education quality and access have not been able to fully provide equal chances and opportunities for all the people as shown in the assessment of Indonesia's education conditions in Table 1.

Observing the education conditions in Indonesia, which ranked 36 out of 49 countries, provides us with an illustration that the performance and quality of education are still far behind other neighboring countries. When comparing education levels within the ASEAN

\footnotetext{
${ }^{2}$ Anis R. Baswedan, former Minister of Education and Culture, stated during a friendly gathering with heads of provincial/regional/municipal education offices throughout Indonesia in 2014.
}

region, Indonesia ranks $5^{\text {th }}$ with a score of 0.603 out of 9 countries, and it is below Singapore, Malaysia, Brunei, and Thailand. ${ }^{3}$ Indonesia's low education level is caused by several factors in which one of them is Indonesia's geographical conditions as an archipelagic state that consequently leads to the unequal access to education or the prevalence of educational inequality among the regions.

Southeast Sulawesi Province is a region that possesses such geographical conditions with the presence of remote islands and coastal areas being a specific issue driving the process of educational disparity to unfold. These conditions also affect the availability of education infrastructure, the quality of education, and people's access to education. ${ }^{4}$ These issues may subsequently trigger educational disparity in the community, as can be witnessed in the number of villages lacking elementary school infrastructure by as many as 435 villages/sub-districts or $21.78 \%$ in remote areas and islands (Statistics Indonesia Southeast Sulawesi Office, 2014). Based on the background explanation provided above, the

\footnotetext{
${ }^{3}$ https://www.dw.com/id/rangking-pendidikan-negaranegara-asean.

${ }^{4}$ Southeast Sulawesi Province has a population of $2,360,611$ and it consists of 1,340,368 people living in the mainland and 1,020,243 people living in the islands with most of the population employed in agriculture and fisheries (Statistics Indonesia Southeast Sulawesi Office, 2016).
} 
author developed an interest in analyzing the educational disparity pattern developing in the Buton and South Buton Regencies.

Study results of several literature reviews pertaining to decentralization studies in educational disparity show that decentralization policies have not been functioning optimally on account of the dominance of the local elites in the process of education policy in the regions, which still positions power/authority as the most dominant factor in the decision-making process (Bardhan \& Mookherjee, 2005; Malley, 2003).

Conceptually speaking, one of the aims of education decentralization is to get the public and regional government (stakeholders) involved to participate in the management of quality education in accordance with each of the region's potential. The education decentralization policy, aside from being considered as a political policy, is also highly suitable to Indonesia's conditions as mentioned by Paqueo \& Lammert (2000), namely for: (1) regional capacity in funding education; (2) improving education efficiency and efficacy in the respective region; (3) redistributing political power; (4) enhancing education quality; and (5) increasing innovations in order to fulfill the public's expectations.

Education decentralization has deep understanding within the discourse of public administration and political studies, as Gregory J. Cizek via Tilaar (2009) mentioned, there are at least four developments as to why political (administrative) authority and educational authority are interconnected: 1 ) the education budget spent, by both central and regional governments, gradually increases, and the budget allocation for the education sector is decided by the government requiring it to compete with other sectors to obtain a greater portion both at the central and regional levels; 2 ) education policy is always considered as a national issue; 3 ) the issue of education serves as a control for the government, which is understandable since the budget allocation for education is a rather substantial portion and this demands control or involvement of political authority in education management; 4) the public is aware that the government's decisions are significantly influential in the quality of education, for that very reason the public cannot escape from the reality of issues in education.

Paqueo \& Lammert (2000) state that education decentralization provides regional governments the opportunity to make the best decision concerning the implementation of education in their respective regions based on the potential capacity of the region and stakeholders. In addition to being acknowledged as a political policy associated with education, education decentralization is also considered as a policy relating to funding capacity and public participation. One of the most crucial issues in education policy is equality and fairness of public's access to education, which continues to become a seemingly ceaseless and insurmountable public issue. Education policy analysis is, hence, of utmost importance for the sake of providing necessary inputs and criticisms regarding the policy process and contents, to thoroughly examine the marginalized education issue in which the cumulative impact of the analysis can reinforce the idea that public policy is merely for the elite (Morgan, Rein \& Goodin, 2015).

Badruzaman (2009, p. 284) considers social inequality as the existence of an imbalance within society causing very distinct differences in the society, wherein the rich have higher position and more power than the poor. Inequality is defined as imbalance or unequal access in gaining or utilizing available resources, in terms of primary needs such as education, health, housing, and employment. Additionally, inequality may come in the form of secondary needs such as education infrastructure, facilities for human rights advocacy, facilities for political channel, and other facilities. 
Aside from the influences caused by social, economic, and geographical conditions in the distribution of resources among the society, inequality may also be caused by inhibitors that prevent or obstruct an individual to utilize existing access or opportunities. In theory, there are at least two main factors that may impede access and cause inequality, namely: 1) internal factors, which originate from within the individual and the cultural constraint of lacking future orientation on account of being confined in the culture of poverty; 2) external factors, which originate from outside of the individual's capability and occur as a result of policies or the bureaucracy limiting or lessening people's access to utilize the resources available in the society (Lewis, 1983).

In line to the above statement, Bremen (1997, p. 166) states that social inequality is not merely caused by internal factors, as it is more a result of the existence of structural constraints that may limit the public's access and opportunities in making use of available resources. Thus, for the poor it can be said that "the road to the top is full of obstacles", while for the rich, "the road to the bottom is far too easy to pass".

\section{Methods}

This research used the qualitative descriptive approach through data collection techniques of observations, in-depth interviews, and document study analysis. Observations were carried out by conducting direct observations of the social conditions of education for the public and mapping out the educational disparity between central regions and peripheral regions located within a single regency or between regencies, to obtain an initial description of the existing education conditions in the community. In-depth interviews were conducted by involving various stakeholders from the regional government of Buton Regency and South Buton Regency with as many as 48 respondents, consisting of Regents, Regional House of Representatives members (Education Commission), Regional Development Planning Agency (Badan Perencanaan Pembangunan Daerah - Bappeda) personnel (regional secretary and staff), Regional Education Services personnel, members of the Education Board, education practitioners, principals, and teachers. The document study was conducted by analyzing data obtained from the relevant regional services containing information to complement data results collected during observations and in-depth interviews in this study on educational disparity and decentralization in the islands of Buton and South Buton Regencies. Subsequently, to ensure the research data's accuracy, the results of the study data were put through a triangulation process between the three types of collected data, namely observation data, interview data, and documentation study results.

\section{Results}

Decentralization in the field of education is a political product of the government implemented to generate equal provision of education services among the public. The findings and study analysis conducted concerning decentralization policy and educational disparity indicate that improvement of education quality and access in the Buton and South Buton Regencies remains highly determined by political actors in formulating the process of education policy, which is full of vested interests and tends to emphasize the use of center-region-based spatial approach and structural approach via political lobbies of educations elites in the region. The low level of education quality and access in the community asserts that education policy takes part in causing educational disparity. The prevailing education policy is considered to lack sensitivity toward socio-cultural, economic, and geographical elements, hence it has yet to provide a sense of equality to the 
educational needs of the public (Nguyen, 2011). Such conditions further affirm the fact that government policies in the field of education have a part in the process of the ever widening educational disparity, both at the district and regency levels.

\section{Disparity in Education Infrastructure in the Regencies}

Decentralization policy in the field of education pertaining to expansion of education access and enhancement of education quality in the Buton and South Buton Regencies still struggles with the vital issue of access to quality education for the public. According to the research findings, the expansion of access to education developing in the Buton and South Buton Regional Administrations, which is aimed at enhancing the quality of educational infrastructure in the region, still seems to be using the spatial and structural elite approaches. Development policies in the field of education so far have not been analyzed comprehensively by considering socio-cultural, economic, and geographical elements present in the community. In accordance with the above issue, the education condition in Buton and South Buton Regencies is still confronted by three main problems, which are: disparity of education infrastructure; quality of education; and access to education. These issues continue to develop consequently widening the gap between the central and peripheral regions.

Meanwhile, according to results of mapping and analysis on studies of decentralization policies and educational disparity, it was found that the lack of availability in education infrastructure and facilities among central and peripheral regions can actually drive educational disparity among schools both at the district and regency levels. The pattern of the governments' development policy in the field of education remains focused on regions that serve as the center of government and administration. Whereas the conditions of education infrastructure in the peripheries are limited to availability of school buildings (classrooms), utilized as a place to conduct learning, and they have not been complemented by similar education infrastructure stipulated in the Regulation of the Minister of Education and Culture No. 23/2013 on Minimum Service Standard for Elementary Education in Regency/ Municipality.

Such conditions have an impact on educational disparity among schools in the central and peripheral regions. The educational disparities found in the regions can be observed in the level of education infrastructure availability of each school scattered throughout Buton and South Buton Regencies. Educational disparity can be seen in the level of education infrastructure and facilities available in those regions, which consist of the availability of a library, science laboratory, computer laboratory, and teacher/principal room (office). The study results obtained from eight districts in Buton Regency and South Buton Regency indicate that not all elementary schools (Sekolah DasarSD) have basic education infrastructure such as a library, a teacher's room, and an office that can be adequately used by teachers and students in order to support a minimum service standard in the learning process conducted at school.

Availability of elementary school education infrastructure and facilities in two areas that serve as Buton Regency's center of administration, namely Pasarwajo District and Wabula District, was found to have reached an average of $80 \%$ and $62 \%$ respectively. Whereas the level of education infrastructure availability of districts located in peripheral areas, namely Siontapina District and Woloa District, was found to have reached an average of merely $36 \%$ and $21 \%$ respectively. Based on the data, it can be stated that the level of education infrastructure availability in areas of district administrative center in Buton Regency reached an average of $71 \%$, while the level of education infrastructure in peripheral areas had 
an average of merely $28.5 \%$. Such conditions provide an illustration that there is still a rather wide gap in education infrastructure between central and peripheral areas by as many as $45.5 \%$.

Meanwhile, research findings related to the distribution of educational resources of elementary schools in two central districts of South Buton Regency show that Siompu District had an average education infrastructure availability level of $26.67 \%$, while West Siompu District had an average of $12.50 \%$. Whereas two districts located in peripheral areas, namely Kadatua District and Batu Atas District, had education infrastructure availability levels of $4.17 \%$ and $5.56 \%$ respectively. The disparity of education infrastructure occurring between these districts shows that the public's access to education still produces a rather wide disparity that has yet to be resolved by the regional governments. It is even more discouraging as there were still a number of elementary schools that did not have any basic education infrastructure such as a library, an office, and a teacher's room.

The educational disparity found at the elementary school (SD) level is, in fact, not much different with the educational disparity occurring at the intermediate school (Sekolah Menengah Pertama-SMP) level. Study results show that the facilities and infrastructure availability level of intermediate schools (SMP) in two districts that serve as the administrative center of Buton Regency's, which are Pasarwajo District and Wabula District, was at an average of $85.2 \%$ and $76.2 \%$ respectively. Meanwhile, the infrastructure availability level of SMP in peripheral areas, namely Woloa District was at an average of $33 \%$ and Siontapina District at an average of $50.2 \%$. Based on these findings, it can be concluded that the level of education infrastructure availability for SMP in administrative center areas reached $80.7 \%$, while peripheral areas at $41.6 \%$, which implies that there is a rather wide gap in education infrastructure between central and peripheral areas by as many as $39.1 \%$.

As for the South Buton Regency, the education infrastructure availability level of SMP in the administrative center areas of Siompu District and West Siompu District was at an average of $36 \%$ and $26.6 \%$ respectively. Whereas the education infrastructure availability level of SMP in the peripheral areas of Kadatua District and Batu Atas District was at an average of $44 \%$ and $30 \%$ respectively. Observing the education infrastructure availability level in South Buton Regency, there was relatively no significant differences between the areas. However, upon closer examination, the level of education infrastructure availability in the peripheral areas of South Buton Regency was found to be very disheartening, there were even some schools in Batu Atas District that did not have a library and computer laboratory.

The low level of education infrastructure availability in these regions provide an illustration of the education development policy pattern found in the regions, which is still inclined toward using two main approaches, namely the spatial approach and the structural elite approach. The spatial approach is an approach that still take into consideration the dichotomy between central administrative areas and peripheral areas. This is in line with statements of Regional House of Representatives (Dewan Perwakilan Rakyat Daerah-DPRD) members and structural elites in the education bureaucracy who explained that the process of improving access to and enhancing the quality of education involves extremely complex indicators. Therefore, a scale of priorities is required to show that there are evident differences between the central areas and the peripheral ones. Policies relating to improving education quality in the regions, so far, have not employed any comprehensive analysis regarding the provision of equal chances and opportunities in improving the quality of public education. 
As for the structural elite approach, it is an approach utilized by principals to perform political lobbying of the regional government (education bureaucracy) for the sake of gaining education fund assistance in the form of education infrastructure procurement projects. ${ }^{5}$

This is in line with a number of statements given by the school principals in the Buton and South Buton Regencies, wherein the structural elite approach model via political lobbying is the fastest and most effective means to realize their request for education fund assistance by renovating school buildings or building more classrooms. The structural elite approach model is often utilized by school principals as it is considered highly effective in realizing the school's educational necessities. Whereas, if they were to wait for the request proposal for education fund assistance according to proper procedures and mechanisms of the regional government through the regional education services, they would most likely be given a less positive response and it would be time consuming along with numerous reasons that the proposal would be accommodated for further assessment and review to ensure the education infrastructure needs of each school $^{6}$. Such reality indicates that state's presence in providing public services has not been able to entirely afford equal opportunities to communities living in varying social, economic, and geographical conditions, hence access to quality education still tends to be discriminatory. According to Sen (2000) and Seach (2005), the social gap does not only deal with the income gap, but it is more complex and

\footnotetext{
${ }^{5}$ Based on mapping results of education infrastructure conditions and interviews with a number of principals in Buton and South Buton Regencies, it is found that as principals, they do not see themselves as only sitting quietly in their schools, but they should be pro-active in visitingt the regional education services office to seek available opportunities relating to education funding assistance programs.

${ }^{6}$ Results of interviews with several school principals in Buton and South Buton Regencies (November 21 and 27, 2017).
}

is related to social and political vulnerability concerning the public's access to education infrastructure.

\section{Disparity in Education Infrastructure Among Regencies}

The decentralization policy as a part of the political products made in order to implement Law No. 23/2014 on Regional Autonomy are aimed at creating regional governments that are effective and efficient in achieving equal provision of education services to the public. Nevertheless, this does not necessarily guarantee equal provision of services concerning public's access to education. One of the inhibitors leading to educational disparity in the regions is bureaucratic pressure or government policies that lower an individual's access to utilize resources available in the society (Lewis, 1983). Educational disparity was not only observed to take place between administrative center areas and peripheral areas within a single region, but it was also witnessed at the regency level.

According to results of analysis on the level of elementary school education infrastructure, the average level of education infrastructure availability in Buton Regency was as many as 59\%, implying that there were $41 \%$ of schools still lacking proper education infrastructure. Meanwhile, the level of elementary education infrastructure availability in South Buton Regency was merely $13 \%$, which means that there were still $87 \%$ of schools lacking adequate education infrastructure. Upon observation of the conditions relating to education infrastructure in the two regencies, it is apparent that there is still a rather spacious gap between Buton Regency and South Buton Regency in terms of education infrastructure availability with a margin reaching $128 \%$.

The form of educational disparity occurring at the elementary school level is, in fact, similar with the disparity of education 
infrastructure found in intermediate schools. The education infrastructure availability of SMP in Buton Regency showed an average reaching $72 \%$, which implies that there were still $28 \%$ of intermediate schools without proper education infrastructure. Whereas in South Buton Regency, the education infrastructure availability level merely reached $37 \%$, which means that there were still $63 \%$ of schools lacking adequate education infrastructure. According to the results of the analysis on education infrastructure availability level acquired, Buton Regency and South Buton Regency may be identified as having a significantly wide gap in education infrastructure availability level by as many as $100 \%$. What is even more discouraging is the fact that out of the 15 intermediate schools visited in South Buton Regency, none of them had any computer laboratory. This stands in stark contrast to the availability of computer laboratory in Buton Regency, which reached as many as $50 \%$.

The concept of decentralization is not easy to define as it possesses highly complex dimension and form. Rondeneli (1986) defined decentralization as the transfer of responsibility in planning, management, and allocation of resources from the central government to its subordinating organization. Therefore, regional governments should be capable of managing and distributing resources and authoritative responsibility (concerning education) justly and fairly for the sake of public welfare.

\section{Disparity in Education Quantity and Quality}

The decentralization policy is part of a long and complex political process that has ramifications on changing the public's social educational life. One of the classical problems confronted by regional governments in terms of education today is the unequal quality of education across Indonesia. The decentralization policy and the gap in education are never-ending topics of debate, interregional educational disparity is an inescapable social reality found in the society. According to the Human Development Index (HDI) published by the Ministry of National Education in 2017, the Southeast Sulawesi Province had an HDI of 69.31 or 0.693 . This places Southeast Sulawesi Province in moderate category with a rank of 19 out of 34 provinces. Meanwhile, the Human Development Index of Buton Regency was at 63.69 and ranked 12 in Southeast Sulawesi Province. Whereas South Buton Regency was ranked 17 or last with an index score of 62.55 (Ministry of National Education, 2017).

The state of Buton and South Buton Regencies' HDIs are undoubtedly inseparable from the role of both central and regional governments in the political process that led to the birth of the decentralization policy. Buton and South Buton Regencies are both located in the islands and they play a part in the advancement and decline of education quality in Indonesia today. Educational disparity in Buton Regency and South Buton Regency may be considered as the sum accumulation of the regional government's policies in improving access to and quality of education in the community. The lack of teacher availability, competence, and educational qualifications in the regions is associated with the decentralization policy's political process that brought about the unfavorable behaviors of structural and political elites in designing education policies in the regions.

The dominance of structural and political elites in the education policy process at the very least impacts conditions pertaining to the disparity of education personnel, civil servant $(A S N)$ teachers and honorary teachers, in Buton and South Buton Regencies. In addition to issues of education infrastructure and libraries as a source of learning, disheartening conditions related to a gap in the inadequate availability of teachers as one of the main source of learning for students in schools were also found. Teachers are one of the first and foremost sources of learning in the pedagogical 
Figure 1.

Distribution of Teachers in Buton Regency and South Buton Regency

\section{Buton Selatan}

Buton

\begin{tabular}{|l|c|c|}
\cline { 2 - 3 } \multicolumn{1}{c|}{} & Buton & Buton Sel atan \\
\hline - Guru PNS & 59.04 & 43.64 \\
\hline - Guru Honorer & 40.96 & 56.36 \\
\hline
\end{tabular}

Source: Regional Education Services (schools) of Buton Regency and South Buton Regency (compiled in 2018).

process taking place in schools. Teacher availability level in South Buton Regency showed that the number of $A S N$ teachers only reached $41 \%$ for elementary school level and $40 \%$ for intermediate school level. Whereas the amount of honorary teacher availability reached 59\% for elementary school level and $60 \%$ for intermediate school level. Differing conditions were observed in Buton Regency with $A S N$ teacher availability level that was far greater than that of the honorary ones. The level of ASN teacher availability in Buton Regency reached $61 \%$ for elementary school level and $57 \%$ for intermediate school level, while the amount of honorary teacher availability was only at $39 \%$ for elementary school level and $43 \%$ for intermediate school level. Observing the composition of teacher availability among the regions, it can be construed that South Buton Regency still experienced an imbalance in the quantity of education personnel, as indicated by the percentage of honorary teacher availability being much greater than the availability of $A S N$ teachers, shown in the figure 1.

Teachers hold a crucial role and are the main actors in improving and enhancing the quality of education in the community. The lack of education personnel is the most basic problem in the world of education, particularly in relation to the quality of education, as without teachers it would prove difficult for schools to achieve quality education. The decentralization policy is, in fact, not necessarily capable of working optimally in resolving education issues in the regions, as it also has significant impact in causing educational disparity in the community, be it within a single regency/region or among regencies/regions. Sachs (2005) in his study concerning The End of Poverty states that one of the mechanisms in eradicating poverty is by developing human capital through the education sector. In developing human capital, Sachs explains that in order to reduce social gaps, several factors are required in which one of them is the availability of skilled and educated human resources in the community.

The low level of education quality in the regions indicates that the regional government's commitment to improving the access to and quality of education remains low, this is apparent in the lack of the regional government's determination in addressing the lack of education personnel by not promoting honorary teacher to become ASN teachers. However, the policy relating to the promotion of honorary teacher, which is achieved through the decree of the regional head (regent), does not directly resolve the lack of education 
personnel in the regions, it would instead lead to new problems as the regional government does not have sufficient budget to pay for the salaries of these honorary teachers. This burden is instead assumed by each of the school according to their needs, wherein the budget load for honorary teachers is allocated in the school's operational assistance fund with the amount of given salary being determined by the respective schools. The amount of salary honorary teachers receives each month (IDR $250,000-300,000)^{7}$ can be regarded as extremely discouraging as it is nowhere near the regional minimum wage, hence it is sometimes difficult to demand quality without considering quantity as they can be perceived as inseparable two sides of the same coin.

\section{Education Accessibility in Peripheral Areas}

The policy on equal and expansive education accessibility is a national policy program that subsequently becomes the guideline for regional governments in designing plans for strategic issues related to improving access to and quality of education in the community. Achieving educational equality by providing accessible education services that include, among others, distance, infrastructure, quality, and cost of education is a part of the regional government's strategic plan to provide education that is democratic, transparent, just, and equal for all its citizens.

The disparity in access to education is a condition lacking equality in the provision of education services in the regions, and it has become a strategic issue to indicate that regional autonomy is unable to provide equal freedom in accessing quality education. The disparity in public's access to quality education serves as a vital element in examining the role of the regional government in designing education policies based on principles of similarity and

\footnotetext{
${ }^{7}$ Interviews with several honorary teachers in Buton Regency and South Buton Regency (November 20 and 23, 2017).
}

differences found in the community. Buton Regency and South Buton Regency are two regional governments that have a rather wide gap in terms of education infrastructure availability through access to learning resources that support the education process in the community.

The decentralization policy is an antithesis of the centralistic policy, and it is implemented for the sake of creating equal education service provision for the public. Education reform, which is conducted through the regional autonomy policy and is expected to be able to bring about change and more democracy in the centralistic education policy pattern, has become a paradox for the public instead. Concomitant with the implementation of the decentralization policy, the education policy pattern is unable to optimally perform and bring about all-around change in improving education access and quality, as observed from the level of learning resources availability accessible by the public both at the district and regency levels. The regional government's education policy pattern that still emphasizes on the spatial development model by prioritizing central areas as the center of development, consequently, drives disparity in the public's access to education to occur.

Problems relating to the gap in access to education infrastructure are a social reality that continues to haunt the education world as of current. Regional governments have not been able to fully ensure equal and uninhibited education service that is accessible for all citizens. The disparity of access to learning resources in Buton Regency and South Buton Regency indicates a rather wide educational gap as shown in the following figure.

According to the figure above concerning the access to three learning resources, namely library, science lab, and computer lab, in Buton Regency and South Buton Regency, it is known that the level of learning resources availability in Buton Regency reached an average of $63 \%$, 
Figure 2.

Access to Learning Resources in Buton Regency and South Buton Regency

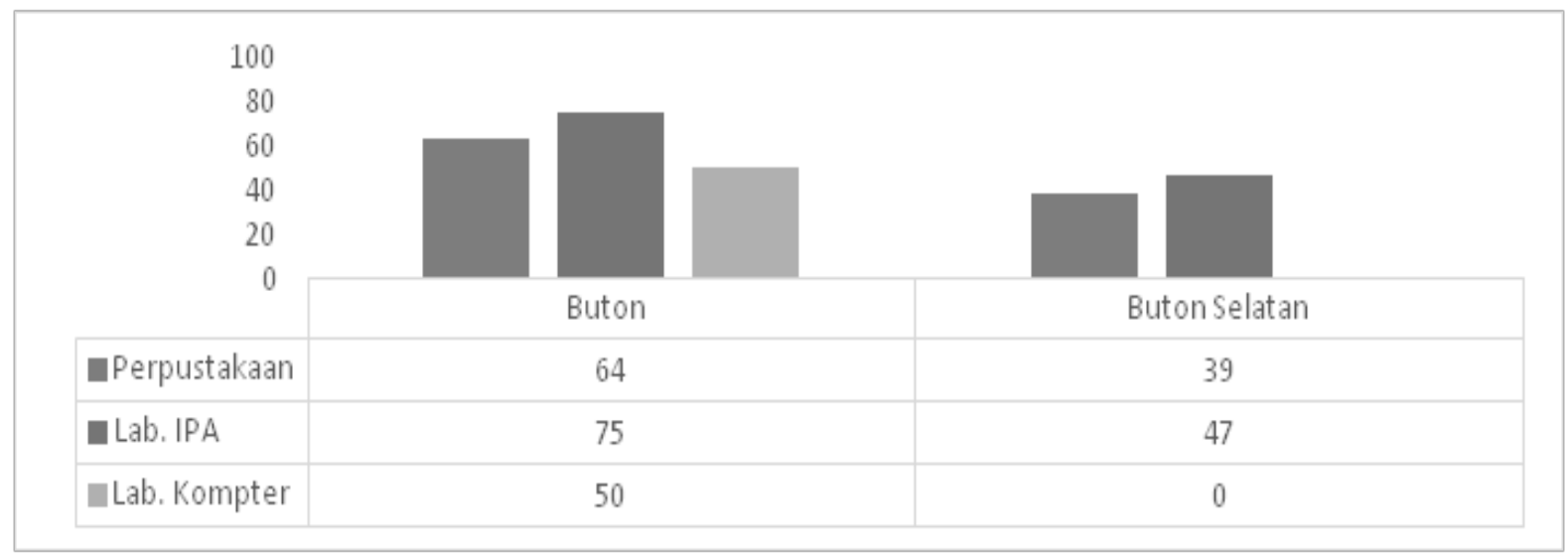

Source: Regional Education Services, (compiled 2018).

while in South Buton it reached an average of merely $26.6 \%$. The level of library, science lab, and computer lab availability in Buton Regency and South Buton Regency indicates that the lack of access to learning resources in schools indirectly affects the quality of education conducted through the pedagogical process in schools. The more learning resources made accessible to students, the better the pedagogical process is.

Learning resources play a substantial role in supporting the quality of the learning process taking place at schools because learning resources are not only required by students in their learning, but teachers should also be supported by adequate learning resources in order to appropriately have proper teaching materials on hand. As of current, the availability of learning resources for students in Buton Regency and South Buton Regency remains discouraging as not all schools possess library and textbooks that are necessary for the lessons conducted in those schools. Such lack of existing learning resources is undoubtedly counterproductive to the School Literacy Movement Program initiated by the Ministry of Education and Culture, which compels all school children to start their learning activities by reading any kind of literature for a duration of 15 minutes before the class begins. ${ }^{8}$

Other than access to learning resources, one of the issues in education that still requires serious attention from the regional governments is the availability of transportation access that supports the process of implementing and enhancing quality education in the regions. Discussions on education policy and improvement of access to and quality of education are surely inseparable from supporting sectors such as the availability of transportation services. Specifically, access to transportation in the islands and peripheries remains to be a classical issue for students and teachers in support of the education process they undertake.

Buton Regency consists of several islands and is divided into seven districts with an area covering $1182.4 \mathrm{~km}^{2}$ and a population density of 83 persons per $\mathrm{km}^{2}$, and in one of the land areas, it is supported by land transportation connecting between one region and another making it less difficult for the community to gain access to education. Based on observations conducted at the location of study, it can be described that Buton Regency, generally, has adequate transportation infrastructure in place

\footnotetext{
${ }^{8}$ Ministerial Regulation No. 23/2015 on developing the reading habits of students.
} 
compared to the transportation conditions in South Buton Regency. The transportation access in Buton Regency has, so far, been supported by sufficient transportation, for both inner city transport and intercity transport, which facilitates the public in accessing places of education in a quick and timely fashion.

As for South Buton Regency, it has geographical conditions that are quite similar to Buton Regency, consisting of seven districts wherein three of the districts are located in the mainland of Buton Island and four of them are located in the islands. It covers an area of \pm $2,988.65 \mathrm{~km}^{2}$ or 298,865 hectares which consists of $\pm 509.92 \mathrm{~km}^{2}$ or 50,992 hectares of land area and approximately $\pm 2,478.73 \mathrm{~km}^{2}$ or 247,873 hectares of marine area. The geographical conditions of South Buton Regency consist of mountainous terrain and islands, which explains the fact that gaining access from one area to another requires transportation access availability along with sufficient amount of transport in order to support the public's access to education. The research findings clarify that there is still a wide disparity in transportation access availability between Buton Regency and
South Buton Regency, particularly in relation to inner city transportation support that can facilitate the process of education, as shown in the transportation access mapping below.

\section{Discussion}

This study provides an explanation on the effect public policy theory has on educational disparity with two main channels, namely the structural elites and the political elites, in the education policy process in the region. Theoretically speaking, education policy in the region involves various actors at the bureaucratic, legislative, and even community levels. In its implementation, the main actors in education policy are always the bureaucratic elites and political elites who strive to achieve equal education provision in the region. Meanwhile, the role of the community in the education policy process is merely as a complementary actor, they are even considered as mere listeners of results from the regional government's work program. The public's function as social control in every regional government policy process is only considered as symbolic and public representation has

Figure 3.

Transportation Access to Education in Buton Regency and South Buton Regency

\begin{tabular}{|c|c|c|c|}
\hline \multicolumn{4}{|l|}{ Buton Sel atan } \\
\hline \multicolumn{4}{|l|}{ Buton } \\
\hline 0 & 20 & 40 & 60 \\
\hline & Buton & Buton Sel atan & \\
\hline Mobil Truk & 44.91 & 48.06 & \\
\hline Mobil Dalam Kota & 27.31 & 0.00 & \\
\hline - Mobil Antar Kota & 27.78 & 51.94 & \\
\hline
\end{tabular}

Source: Public Works Services and Statistics Indonesia South Buton Office (compiled in 2018). 
always been represented by the political elites (legislative).

Discussions on the technical process of education policy in the region begin with the specific reality of a region in the work plan process composed by the regional education services office. During the drafting of policy agenda, the regional education services office collaborates with the elementary school sector and school principals to formulate the annual work plan for the education sector under the supervision of the head of education services as the person in charge of education in the region. The results of the regional education services annual work plan are subsequently proposed to the Regional Development Planning Agency (Badan Perencanaan Pembangunan Daerah Bappeda) for a hearing and to be included as a part of the Regional Development Work Plan (Rencana Kerja Pembangunan Daerah-RKPD). The dynamics of education policy contestation at the bureaucratic level is the initial phase in the contestation of interests among bureaucratic elites, namely the regional education services office (Diknas) and Bappeda, in formulating the regional education policy. Differences of opinions between Diknas and Bappeda in drafting the work program in the education sector often lead to an impasse on account of differences in perspectives concerning the strategic plan of the regional work program in the education sector, and the regional education services office is constantly positioned under the control of Bappeda. Such differences of opinions subsequently lead to conflicts of interests with considerations given to scale of priority and disregarding work program composed by the regional education services office as the institution responsible for the education sector in the region. Meanwhile, the regional education services office considers the work program they made to be in accordance with the strategic plan of the education sector, which in part is instigated by the basic and real conditions found in a country, namely the social, economic, and geographical conditions in the community. The contestation among structural elites in the region serves as a starting point in the elite's dominance over the work program, which subsequently changes the education policy's orientation and, consequently, brings about unfavorable behaviors of bureaucratic elites in the education policy process, ultimately affecting educational disparity between the central and the peripheral regions. The contestation process and the elite's dominance in the policy process continue to the level of political elites, pitting the executive against the legislative, and are, eventually, manifested in the education policy orientation both at the regional and national levels.

\section{Conclusion}

Education policy aimed at improving access to and quality of education in Buton Regency and South Buton Regency has always developed via two main approaches, namely the spatial approach and the structural elite approach which are focused on central rather than peripheral areas. The high level of disparity in education infrastructure between the central and the peripheral areas indicate a tendency of education policy being focused on areas of administrative significance or centers of government. The level of education infrastructure availability in peripheral areas, thus far, remains limited to meeting the requirement of school building availability as a place of learning and not providing them with adequate education infrastructure support in accordance with the minimum service standards stipulated in the Regulation of the Ministry of Education and Culture of the Republic of Indonesia No. 23/2013. Educational disparity not only takes place at the district level, but at the regency level as well, as observed in the level of education infrastructure availability, quality of education, and education accessibility available in central and peripheral areas.

The pattern of educational disparity in 
Buton Regency and South Buton Regency is in most part caused by regional development policy that tends to emphasize the development of education infrastructure in central areas by using two main approaches, which are the spatial approach and the structural elite approach. The pattern of spatial development policy is part of the regional government's strategic plan to establish legitimacy and regional development strategy based on a priority scale. Meanwhile, the structural elite approach relates to regional government (education services office) work plan to distribute education assistances to schools by using the social interactions of structural elites through political lobbying carried out by school principals on the bureaucratic elites of the education sector in order to gain education fund assistance in the form of infrastructural physical development fund for education. The social interactions of political elites is not only conducted in central areas but in peripheral areas as well, with the purpose of justifying that the development policy in the education sector in the region has been carried out in line with the existing mechanism, and the procedure has been conducted through collaborative development planning mechanism by using a technocratic, democratic, participatory, political approach coupled with the bottom-up and top-down process.

\section{References}

Badruzaman, A. (2009). Dari teologi menuju aksi (membela yang lemah, menggempur kesenjangan). Yogyakarta: Pustaka Pelajar.

Bardhan, P. \& Mokherjee, D. (2005). Capture and Governance at Local and National Levels, American Economic Review, 90(2), 135-139.

Bremen, J. (1997). Menjinakkan sang kuli, politik kolonial pada awal abad ke-20. Jakarta: Pustaka Utama Grafiti.

Budge, I. \& H. Keman. (1990). Parties and democracy: Coalition formation and government functioning in twenty state. London: Oxford
University Press.

Dorius, S. F. (2013). The rise and fall of worldwide education inequality from 1870 to 2010: measurement and trends. Sociology of Education, 86(2), 158-173.

Drost, J. I. G. M. (1998). Sekolah: mengajar atau mendidik. Yogyakarta: Kanisius.

Fiske, E. B. (1996). Decentralization of education: Politics and consensus. Washington: World Bank.

Lewis, T. (2007). Social inequality in education: a constraint on an american high-skills future. Curriculum Inquiry, 37(4), 329-349.

Malley, M. S. (2003). New rules, old structures and the limits of democratic decentralization. In E. Aspinall \& G. Fealy (Eds.), Local power and politics in Indonesia: Decentralisation and democratisation (pp. 102-116). Singapore: Institute of Southeast Asian Studies.

Montt, G. (2011). Cross-national differences in educational achievement inequality. American Sociological Association, 84(1), 49-68. doi: 10.1177/0038040710392717.

Morgan, M., Rein, M. \& Goodin, R. E. (2015). Handbook Kebijakan Publik. Bandung: Penerbit Nusa Media.

Nelson, J. L., Palonsky, S. B., \& Keneth Carlson. (1996). Critical issues in education: Dialogues and dialectics. New York: McGraw-Hill Companiers.

Nguyen, M. (2011). Closing the education gap: A Case for Aboriginal Early Childhood Education in Canada, ALook at the Aboriginal Headstart Program. Canadian Journal of Education, 34(3), 229-248.

Paqueo V., \& Lammert. J. (2000). Decentarlization in Education. New York: Education Reform dan Management Thematic Group.

Rondinelli, D. A., \& G. Shabbir Cheema. (1988). Implementing Decentralization Policies an Introduction. In Chemma \& Rondinelli (Eds.), Decentralization and development: Policy implementation in developing countries. California: Sage Publication Inc. 
Sach, J. D. (2005). The end of poverty. New York: Penguin Press.

Sen, A. K. (2000). Development as freedom. New York: Anchor Books.

Tilaar, H. A. R, \& Nugroho, R. (2009). Kekuasaan dan pendidikan: Manajemen pendidikan nasional dalam pusaran kekuasaan. Jakarta: PT Rineka Cipta.

Walters, P. B. (2001). Educational access and the state: historical continuities and discontinuities in racial inequality in american education. American Sociological Association, 74(2001), 35-49. doi: $10.2307 / 2673252$

Wibowo, U. B. (2011). Politik dan kebijakan pembaharuan pendidikan: mencari pijakan operasional yang akuntabel. Dinamika Pendidikan, 2, 72-86. 